Vol. 7 (1998): 569-581.

\title{
Nitrogen and phosphorus losses in surface runoff and drainage water after application of slurry and mineral fertilizer to perennial grass ley
}

\author{
Eila Turtola \\ Agricultural Research Centre of Finland, Plant Production Research, FIN-31600 Jokioinen, \\ Finland, e-mail: eila.turtola@mtt.fi \\ Erkki Kemppainen \\ Agricultural Research Centre of Finland, FIN-31600 Jokioinen, Finland
}

\begin{abstract}
Losses of nitrogen $(\mathrm{N})$ and phosphorus $(\mathrm{P})$ from perennial grass ley on a fine sand soil were studied with five treatments: no fertilizer (1), cow slurry applied in autumn (2), winter (3) or spring (4), and mineral fertilizer applied in spring (5). For N, the total amounts applied (1992-96) were 0, 772, 807, 805 and $510 \mathrm{~kg} \mathrm{ha}^{-1}$ and for P $0,141,119,143$ and $107 \mathrm{~kg} \mathrm{ha}^{-1}$, respectively. In the first year (establishment of the ley, 1992-93), N losses (drainage + surface runoff) were slightly higher after application of slurry in autumn (with immediate ploughing, treatment 2$)$ than in treatments 1,4 and $5(21 \mathrm{~kg}$ ha $^{-1}$ vs. $\left.17 \mathrm{~kg} \mathrm{ha}^{-1}\right)$, but the respective P losses $\left(0.7-0.9 \mathrm{~kg} \mathrm{ha}^{-1}\right)$ were not affected. During the ley years (1993-96) the $\mathrm{N}$ and $\mathrm{P}$ losses were increased by surface application of fertilizers and by abundance of surface runoff (83-100\% of the total runoff). Nutrient losses were extremely high after slurry application in autumn and winter, accounting for $11 \%$ and $33 \%$ of the applied $\mathrm{N}$ and $17 \%$ and $59 \%$ of the applied $\mathrm{P}$, respectively. The $\mathrm{N}$ losses during the ley years from treatments 1-5 were 13, $62,191,23$ and $24 \mathrm{~kg} \mathrm{ha}^{-1}$, where the proportion of $\mathrm{NH}_{4}-\mathrm{N}$ was $21,49,56,33$ and $39 \%$. The respective $\mathrm{P}$ losses were $0.73,16,54,4.2$ and $4.0 \mathrm{~kg} \mathrm{ha}^{-1}$, where the proportion of $\mathrm{PO}_{4}-\mathrm{P}$ was $52,85,77,68$ and $64 \%$.
\end{abstract}

Key words: ammonium-N, application time, orthophosphate-P, surface application

\section{Introduction}

Fertilizing with slurry is often followed by high losses of nitrogen $(\mathrm{N})$ and phosphorus $(\mathrm{P})$ due to application in excess amounts or unsuitable timing relative to crop requirements (Kemppainen 1995, Oskarsen et al. 1996, Carey et al. 1997,
Paul and Zebarth 1997). Compared with cereals, fields under perennial ley are normally less prone to nutrient losses, and, in spite of the large inputs in manure or slurry, the leaching losses from perennial grass leys are often small (Furrer and Stauffer 1986, Unwin 1986, Eder and Harrod 1996, Cameron et al. 1996). However, several studies have shown high dissolved $\mathrm{P}$ losses

(C) Agricultural and Food Science in Finland Manuscript received September 1998 
Turtola, E. \& Kemppainen, E. N and P losses after application of fertilizers to grass ley

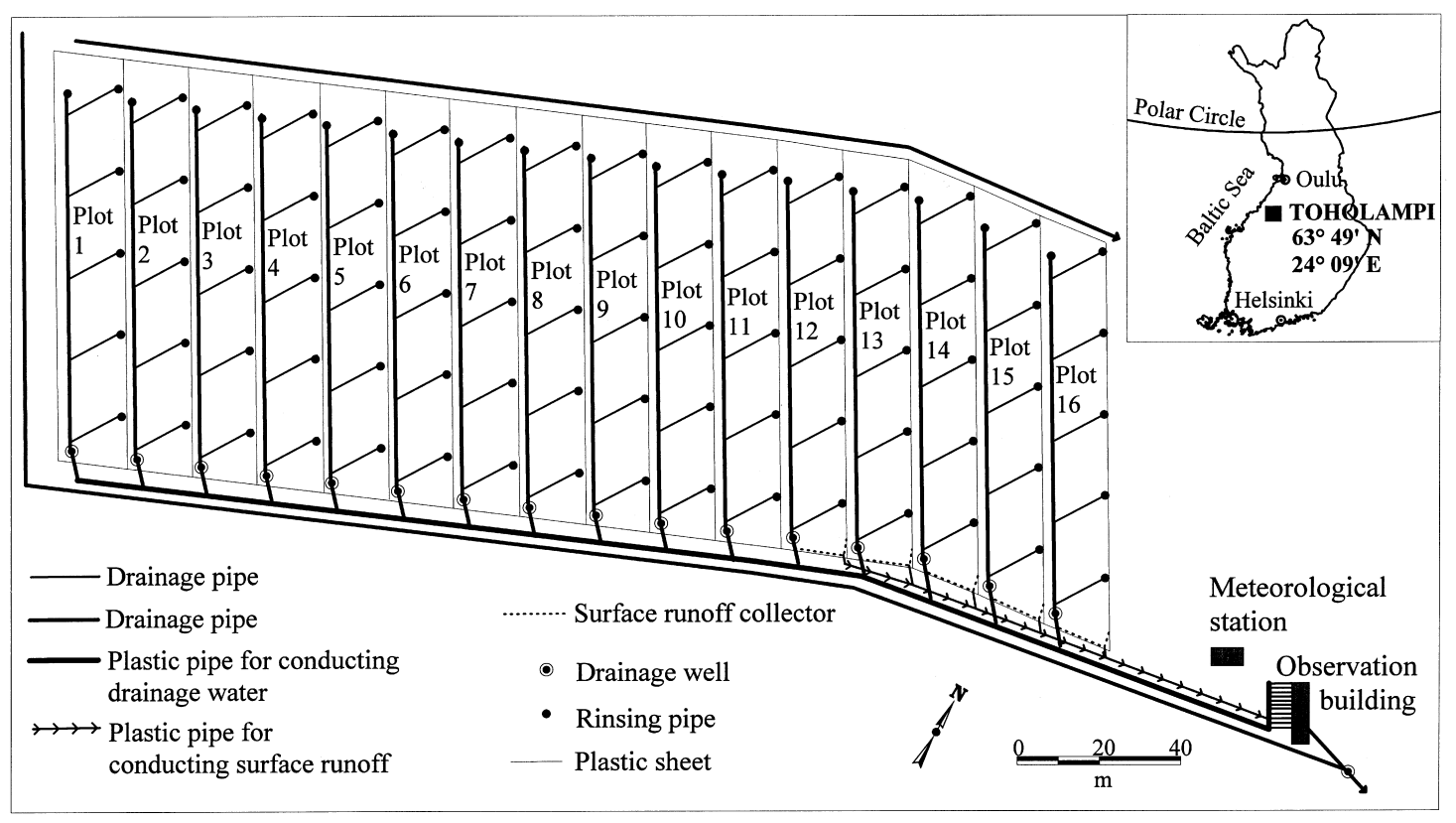

Fig. 1. Map of the experimental field.

in surface runoff from grassland (Uhlen 1978a, Uhlen 1988, Turtola and Jaakkola 1995).

The susceptibility of applied $\mathrm{N}$ and phosphorus $P$ to loss via surface runoff or drainage depends on the physical contact with soil, which may or may not render adsorption of $\mathrm{NH}_{4}^{+}$and $\mathrm{H}_{2} \mathrm{PO}_{4}^{-}$possible, on nitrification of $\mathrm{NH}_{4}-\mathrm{N}$ or immobilization and crop uptake of $\mathrm{NH}_{4}-\mathrm{N}$ and $\mathrm{NO}_{3}-\mathrm{N}$. Surface application of slurry or mineral fertilizers is a common practice during perennial grass cultivation. Surface application leaves the nutrients on the soil surface with little initial contact with adsorbing soil constituents, with the result that the losses in surface runoff are increased (Edwards and Daniel 1993, Misselbrook et al. 1995, Turtola and Jaakkola 1995). Manure and slurry spreading outside the growing season causes high risks of nutrient losses into watercourses (Young and Mutchler 1976, Uhlen 1978b, Braun and Leuenberger 1991, Parkes et al. 1997). The probability of direct losses due to rain or snowmelt water is high especially where the soil is impermeable, e.g. due to frost, or conditions are otherwise favourable to surface run- off. In Finland, owing to insufficient storage capacity and difficulties associated with spring application, about $30 \%$ of manure is spread in autumn (MMM 1998). Previously manure and slurry were also applied in winter on snow-covered or frozen soil but this practice is now to be prohibited by law.

This paper reports the $\mathrm{N}$ and $\mathrm{P}$ losses in surface runoff and drainage water during a four-year experiment, where slurry was either mixed with the surface soil or surface-applied in autumn, winter or spring. The losses are compared with those from mineral fertilized and non-fertilized soil.

\section{Material and methods}

\section{The experimental field}

The experimental field ( $2.56 \mathrm{ha})$ is located on a fine sand soil in Toholampi, western Finland (Fig. 1). Occasional snowmelts during winter, 
Vol. 7 (1998): 569-581.

Table 1. Total precipitation, maximum amount of water in snow in March and dates of snow cover and frost and maximum frost depth during the experimental years 1992-1996 and the average during 1966-96.

\begin{tabular}{|c|c|c|c|c|c|}
\hline $\begin{array}{l}\text { Experimental } \\
\text { years }\end{array}$ & $\begin{array}{l}\text { Total precip. }{ }^{1} \\
(\mathrm{~mm})\end{array}$ & $\begin{array}{l}\text { Max. water in snow } \\
\text { in March }(\mathrm{mm})\end{array}$ & Snow cover (date) & Frost (date) & $\begin{array}{l}\text { Max. frost } \\
\text { depth }(\mathrm{cm})\end{array}$ \\
\hline 1992-93 & 594 & 86 & $10.10 .-5.4 .^{2}$ & 15.10.-26.5. & 62 \\
\hline 1993-94 & 534 & 150 & $11.11 .-10.4 .^{3}$ & 16.10.-12.6. & 58 \\
\hline 1994-95 & 671 & 95 & 8.11.-19.4. ${ }^{4}$ & 10.11.-3.6. & 69 \\
\hline 1995-96 & 486 & 120 & 29.10.-20.4. & 3.11.-9.6. & 66 \\
\hline \multicolumn{6}{|l|}{ Average } \\
\hline $1966-96$ & 583 & & 18.11.-13.4. & 9.11.-30.5. & 63 \\
\hline
\end{tabular}

${ }^{1}$ From 1.9. to 31.8 .

${ }^{2}$ No snow cover: $16.12 .1992-5.1 .1993$

${ }^{3}$ First snow: 10.10 .1993

${ }^{4}$ First snow: 3.10.1994; no snow cover: 20.12.1994 - 2.1.1995

Table 2. Characteristics of the experimental soil at the start of the experiment. Values in parenthesis indicate the range.

\begin{tabular}{llllll}
\hline Depth, cm & $\mathrm{pH}($ water $)$ & Org. C $(\%)$ & $\mathrm{Al}_{\mathrm{ox}}\left(\mathrm{g} \mathrm{kg}^{-1}\right)^{1}$ & $\mathrm{Fe}_{\mathrm{ox}}\left(\mathrm{g} \mathrm{kg}^{-1}\right)^{1}$ & $\mathrm{P}_{\mathrm{Ac}}\left(\mathrm{mg} \mathrm{l}^{-1}\right)^{2}$ \\
\hline $0-25$ & $5.7(5.6-5.8)$ & $5.0(4.8-5.3)$ & $2.6(2.4-2.8)$ & $1.7(1.0-2.6)$ & $6.4(5.1-7.5)$ \\
$25-35$ & $5.2(5.2-5.3)$ & $2.6(2.2-3.1)$ & $3.9(3.5-4.3)$ & $5.2(4.4-6.0)$ & $4.1(2.8-5.5)$ \\
$35-60$ & $5.3(5.2-5.3)$ & $0.3(0.3-0.4)$ & $1.0(0.9-1.1)$ & $4.2(3.7-4.7)$ & $2.7(1.8-3.9)$ \\
\hline
\end{tabular}

${ }^{1}$ Ammonium oxalate (0.5 M, pH 3.3) extractable Al and Fe (Niskanen 1989)

${ }^{2}$ Acetic acid ( $\mathrm{pH} 4.65$ ) extractable P (Vuorinen \& Mäkitie 1955)

Table 3. Particle size distribution and saturated hydraulic conductivity $\left(\mathrm{K}_{\mathrm{sat}}\right)$ in two plots of the experimental soil.

\begin{tabular}{lllllll}
\hline & & \multicolumn{3}{l}{$\begin{array}{l}\text { Particle size distribution }(\%) \text { in different } \\
\text { size fractions }(\mathrm{mm})\end{array}$} & $\mathrm{K}_{\text {sat }}(\mathrm{cm} / \mathrm{h})$ \\
\cline { 3 - 6 } & Depth & $<0.002$ & $0.002-0.02$ & $0.02-0.2$ & $0.2-2$ & \\
\hline \multirow{2}{*}{ Plot 12} & $0-25$ & 5 & 16 & 76 & 3 & 0.38 \\
& $25-35$ & 4 & 22 & 72 & 2 & 0.16 \\
\multirow{3}{*}{ Plot 14} & $35-100$ & 9 & 29 & 62 & 0 & 0.87 \\
& $0-25$ & 4 & 18 & 73 & 5 & 1.6 \\
& $25-35$ & 5 & 21 & 71 & 3 & \\
\hline
\end{tabular}

main snowmelt in March and frost until late May are typical for the study area (Table 1). The soil has been tentatively classified as Haplic Podzol (FAO 1988) and Aquic Haplocryod (Soil Survey Staff 1992). The $25-35 \mathrm{~cm}$ horizon is a spodic horizon, characterized by an abundance of oxalate-extractable $\mathrm{Fe}$ and $\mathrm{Al}$ and a relatively high amount of organic C (Table 2). Over most of the field, the albic horizon and the upper part of the spodic horizon had been ploughed into the $A_{p}$ horizon. The percentage of silt and clay was somewhat higher below $35 \mathrm{~cm}$ depth than above (Table 3). The values of saturated hydraulic conductivity were relatively low (Table 3 ), indicat- 
Turtola, E. \& Kemppainen, E. $N$ and P losses after application of fertilizers to grass ley

Table 4. N, P and K applications (N,P,K, $\mathrm{kg} \mathrm{ha}^{-1}$ ) in fertilizer (f) and slurry (s) and month of treatment during the experimental years 1992-1996.

\begin{tabular}{|c|c|c|c|c|c|c|}
\hline No & Treatment & $\begin{array}{l}\text { 1992-93 } \\
\text { Ploughed }\end{array}$ & $\begin{array}{l}\text { 1993-94 } \\
\text { Ley }\end{array}$ & $\begin{array}{l}\text { 1994-95 } \\
\text { Ley }\end{array}$ & $\begin{array}{l}\text { 1995-96 } \\
\text { Ley }\end{array}$ & Total \\
\hline 1 & Control & None & None & None & None & None \\
\hline 2 & Slurry, Sept. & $\begin{array}{l}\text { 196,49,136 } \\
\text { s, Sept }\end{array}$ & $\begin{array}{l}\text { 193,26,163+91,11,11 } \\
\text { s, Sept + f, July }\end{array}$ & $\begin{array}{l}201,44,154+91,11,11 \\
\text { s, Sept + f, June }\end{array}$ & None & $772,141,475$ \\
\hline 3 & Slurry, Dec. & $\begin{array}{l}226,28,172 \\
\text { s, Dec }\end{array}$ & $\begin{array}{l}207,32,192+91,11,11 \\
\text { s, Jan + f, July }\end{array}$ & $\begin{array}{l}\text { 192,37,218 + 91,11,11 } \\
\text { s, Jan + f, June }\end{array}$ & None & $807,119,604$ \\
\hline 4 & Slurry, May & $\begin{array}{l}211,33,163 \\
\text { s, May }\end{array}$ & $\begin{array}{l}247,61,218+91,11,11 \\
\text { s, May + f, July }\end{array}$ & $\begin{array}{l}165,27,171+91,11,11 \\
\text { s, May + f, June }\end{array}$ & None & $805,143,574$ \\
\hline 5 & NPK, May & $\begin{array}{l}100,35,71 \\
\text { f, May }\end{array}$ & $\begin{array}{l}128,28,52+91,11,11 \\
\text { f, May + f, July }\end{array}$ & $\begin{array}{l}\text { 100,22,42+91,11,11 } \\
\text { f, May + f, June }\end{array}$ & None & $510,107,187$ \\
\hline
\end{tabular}

ing a tendency for surface runoff instead of deep percolation and drainage flow. The slope varies between $0.30-0.74 \%$, with a mean value of $0.54 \%$. Sideways the mean slope is $1.1 \%$.

Plastic drainage pipes $(\varnothing 44 \mathrm{~mm})$ were laid in the field in 1989, $16 \mathrm{~m}$ apart and at a depth of about $1.05 \mathrm{~m}$. The drains were connected to plastic cross pipes $(\varnothing 58 \mathrm{~mm})$ to form 16 separate drainage plots, $16 \mathrm{~m} \times 100 \mathrm{~m}$, i.e. 0.16 ha (Fig. 1 ). The plots were isolated hydrologically from each other and from the surrounding area with $0.3 \mathrm{~m}$ high ridges formed from mounded earth and by a plastic sheet extending to the depth of $1.5 \mathrm{~m}$. The cross pipes carried the drainage water to wells (Ø $300 \mathrm{~mm}$ ), from where the water was conducted to an observation building for volume measurement with tipping buckets. The flow-weighted water samples were collected with funnels conducting $0.24 \%$ of the total discharge to plastic containers for further sampling and chemical analysis. The surface runoff was collected at the lower end of five drainage plots $(12,13,14,15$ and 16) into $0.2 \mathrm{~m}$ deep open ditches strengthened with concrete (Fig. 1). From there the water was conducted through plastic pipes for measurement and analysis.

Water sampling for analysis from the containers was proportional to flow. The drainage water and surface runoff were sampled 17-28 times per year, each sample representing about $7 \mathrm{~mm}$ of surface runoff or drainage water. For the whole experiment (1992-96) the total number of sampling dates was 89 and the average sampling interval 16 days, varying from half a day to four months. Most of the water samples (55\%) were taken in winter-spring, while $30 \%$ were taken in autumn and only $15 \%$ in summer.

\section{Experimental design}

The four-year experiment was performed in 1992-1996 with five fertilization practices (treatments) (Table 4) and three replications, arranged as a randomized complete block design on plots $2-16$. Treatment 1 was the control, receiving no fertilizer. The experiment started with the application of cow slurry in September 1992 (treatment 2). Immediately after the slurry was spread on the soil surface, the soil was ploughed to a depth of $22 \mathrm{~cm}$. In December, slurry was applied on the soil surface, covered with snow (treatment 3 ). (Treatment 3 was included because at the beginning of the experiment slurry spreading on frozen soil was not prohibited but it was only recommended to be avoided.) In May 1993, slurry was applied on the soil surface followed by immediate harrowing of the soil to a depth of 5 
Vol. 7 (1998): 569-581.

$\mathrm{cm}$ (treatment 4). For treatment 5, NPK fertilizer was applied in May by placement technique to a depth of $7 \mathrm{~cm}$ in connection with sowing. For the establishment of the perennial grass ley, spring barley (Hordeum vulgare) was sown in 1993 on all plots, with timothy (Phleum pratense) and meadow fescue (Festuca pratensis) interseeded. After harvesting of the barley in August, the timothy - meadow fescue ley was grown. The ley was cut twice in 1994 and 1995 and once in 1996.

In autumn 1993 and onwards, cow slurry and mineral fertilizer were applied to the soil surface without any incorporation or mixing with the soil. The application for treatment 3 was again done on snow-covered soil. In 1994-1995, supplemental mineral fertilizer was applied in treatments $2-5$ one week after the first cutting of the ley. In treatments $2-4$, the target was that the amount of soluble $\mathrm{N}$ in slurry (55\% of total $\mathrm{N}$ ) should equal the amount of $\mathrm{N}$ applied in mineral fertilizer in treatment 5. For P, the amounts applied in slurry were greater than the amounts applied in the mineral fertilizer (Table 4). No nutrients were applied in 1996 and the ley was ploughed in in autumn 1996.

\section{Chemical analyses}

The water samples were stored and analysed for total nitrogen $(\mathrm{TN})$, nitrate nitrogen $\left(\mathrm{NO}_{3}-\mathrm{N}\right)$, ammonium nitrogen $\left(\mathrm{NH}_{4}-\mathrm{N}\right)$, total phosphorus (TP), dissolved orthophosphate phosphorus $\left(\mathrm{PO}_{4}-\mathrm{P}\right)$ and total solids (TS) as described by Turtola \& Paajanen (1995). TN, TP and TS were measured in unfiltered water samples and $\mathrm{NO}_{3}-$ $\mathrm{N}, \mathrm{NH}_{4}-\mathrm{N}$ and $\mathrm{PO}_{4}-\mathrm{P}$ were measured after filtering of samples through Nuclepore $0.2 \mu \mathrm{m}$ filter. As the concentration of nitrite nitrogen $\left(\mathrm{NO}_{2}{ }^{-}\right.$ $\mathrm{N})$ was not separately determined, $\mathrm{NO}_{3}-\mathrm{N}$ represents the sum of $\mathrm{NO}_{3}-\mathrm{N}$ and $\mathrm{NO}_{2}-\mathrm{N}$. Organic $\mathrm{N}$ was calculated as the difference between $\mathrm{TN}$ and $\mathrm{NO}_{3}-\mathrm{N}+\mathrm{NH}_{4}-\mathrm{N}$. Particulate $\mathrm{P}(\mathrm{PP})$, representing the sum of particulate inorganic or organic $\mathrm{P}$ and dissolved organic $\mathrm{P}$, was calculated as the difference between $\mathrm{TP}$ and $\mathrm{PO}_{4}-\mathrm{P}$.
$\mathrm{N}$ and $\mathrm{P}$ losses were calculated for autumn (mid-September - December), winter-spring (January - April/May) and summer (May/June - mid-September) periods, where each period started from the day of slurry spreading. For the calculation of the annual losses, the starting point was the autumn period (e.g. for the one-year period marked as 1992-93, the losses of autumn 1992, winter-spring 1993 and summer 1993 were summed).

The amount of mineral nitrogen $\left(\mathrm{NO}_{3}-\mathrm{N}\right.$ and $\mathrm{NH}_{4}-\mathrm{N}$ ) in soil was determined in $0-20,20-40$ and 40-60 cm layers in late May in 1993-95. Sampling, storage and analysis of the soil were carried out as described by Esala (1991). The contents of $\mathrm{N}, \mathrm{P}$ and $\mathrm{K}$ in slurry were determined as described by Kemppainen (1989). The crop uptakes of $\mathrm{N}$ and $\mathrm{P}$ were calculated by multiplying the yield by its nutrient concentrations, which were determined according to Kähäri \& Nissinen (1978). N and P balances for the different treatments were calculated by subtracting the total amounts of $\mathrm{N}$ and $\mathrm{P}$ removed from the amounts applied (input). For the removal, the uptake by the harvested crop was added to the losses in surface runoff and drainage.

\section{Statistical analyses}

The drainage water samples and soil samples represented the five different treatments with three replicates. Statistical analyses were done with one-way analysis of variance and subsequent Tukey's test. Variables were the volumes of drainage water and the losses of $\mathrm{NO}_{3}-\mathrm{N}, \mathrm{NH}_{4}-$ $\mathrm{N}, \mathrm{TN}, \mathrm{PO}_{4}-\mathrm{P}$ and $\mathrm{TP}$ in autumn, winter-spring and summer, and the amounts of $\mathrm{NO}_{3}-\mathrm{N}$ and $\mathrm{NH}_{4}-\mathrm{N}$ at the different sampling depths. Owing to the negligible amount of drainage after the first year and the limited movement of $\mathrm{N}$ below the surface soil, only some of the test results are presented. There were no replicates in the surface runoff plots, which made it impossible to test the results for surface runoff statistically. 
Turtola, E. \& Kemppainen, E. N and P losses after application of fertilizers to grass ley

\section{Results}

\section{Drainage water and surface runoff}

In 1992-93, the proportion of autumn and winter-spring total runoff (drainage + surface runoff) was $60-66 \%$ and $33-39 \%$ of the annual total runoff, respectively. The general pattern for the water flow on ploughed soil and barley was dominance of drainage flow in autumn and surface runoff in spring. Surface runoff averaged $40-52 \%$ of the annual total runoff (Table 5), the proportion of surface runoff being in autumn, winter-spring and summer $11-30 \%, 95-96 \%$ and $73-88 \%$, respectively.

During the ley years 1993-1996, in contrast, the proportion of autumn and winter-spring total runoff was lower in autumn (4-29\% and) and higher in winter-spring (67-89\%) than it was in the first year. This was due to lower precipitation in autumn (176-217 vs. $270 \mathrm{~mm}$ ) and more water in snow (maximum amount of water in snow $95-150$ vs. $86 \mathrm{~mm}$, Table 1) in the ley years compared with the first year. Surface runoff from the ley averaged as much as $83-100 \%$ of the annual total runoff, and water discharge from the field during occasional snowmelt in winter and

Table 5. Drainage water and surface runoff $(\mathrm{mm})$ and losses of total $\mathrm{N}(\mathrm{TN})$, ammonium-N $\left(\mathrm{NH}_{4}-\mathrm{N}\right)$, nitrate- $\mathrm{N}\left(\mathrm{NO} \mathrm{O}_{3}-\mathrm{N}\right)$, total P (TP), orthophosphate $\mathrm{P}\left(\mathrm{PO}_{4}-\mathrm{P}\right)$ and evaporation residue (TS) $\left(\mathrm{kg} \mathrm{ha}^{-1}\right)$ during the experimental years $1992-1996$.

\begin{tabular}{|c|c|c|c|c|c|c|c|c|c|c|c|c|c|c|}
\hline \multirow{2}{*}{$\begin{array}{l}\text { No } \\
\text { Treatment }\end{array}$} & \multicolumn{7}{|c|}{ Drainage water, $n=3$} & \multicolumn{7}{|c|}{ Surface runoff, $n=1$} \\
\hline & Water & $\mathrm{TN}$ & $\mathrm{NH}_{4}-\mathrm{N}$ & $\mathrm{NO}_{3}-\mathrm{N}$ & $\mathrm{TP}$ & $\mathrm{PO}_{4}-\mathrm{P}$ & TS & Water & $\mathrm{TN}$ & $\mathrm{NH}_{4}-\mathrm{N}$ & $\mathrm{NO}_{3}-\mathrm{N}$ & $\mathrm{TP}$ & $\mathrm{PO}_{4}-\mathrm{P}$ & TS \\
\hline \multicolumn{15}{|l|}{1 Control } \\
\hline $1992-93$ & 130 & 11 & 0.058 & 9.8 & 0.021 & 0.007 & 260 & 110 & 6.3 & 0.57 & 2.5 & 0.65 & 0.028 & 247 \\
\hline 1993-94 & 32 & 3.3 & 0.016 & 3.1 & 0.007 & 0.001 & 76 & 161 & 2.8 & 1.3 & 0.49 & 0.25 & 0.13 & 102 \\
\hline $1994-95$ & 3.8 & 0.31 & 0.002 & 0.28 & 0.001 & 0.000 & 8.9 & 261 & 3.6 & 1.1 & 1.0 & 0.30 & 0.12 & 145 \\
\hline 1995-96 & 10 & 1.4 & 0.007 & 1.3 & 0.003 & 0.000 & 22 & 151 & 1.6 & 0.28 & 0.26 & 0.17 & 0.13 & 145 \\
\hline $1992-96$ & 176 & 16 & 0.083 & 14 & 0.032 & 0.008 & 367 & 683 & 14 & 3.3 & 4.3 & 1.2 & 0.41 & 639 \\
\hline \multicolumn{15}{|c|}{2 Slurry, Sept. } \\
\hline 1992-93 & 130 & 16 & 0.094 & 15 & 0.038 & 0.014 & 290 & 98 & 5.4 & 0.83 & 2.1 & 0.72 & 0.041 & 248 \\
\hline 1993-94 & 23 & 4.3 & 0.009 & 3.9 & 0.004 & 0.001 & 72 & 376 & 36 & 22 & 3.3 & 9.4 & 8.2 & 582 \\
\hline 1994-95 & 0.5 & 0.070 & 0.000 & 0.063 & 0.001 & 0.001 & 1.8 & 329 & 16 & 7.7 & 1.4 & 5.2 & 4.3 & 293 \\
\hline 1995-96 & 4.0 & 2.5 & 0.006 & 2.2 & 0.003 & 0.000 & 15 & 135 & 2.8 & 0.77 & 0.38 & 0.98 & 0.76 & 142 \\
\hline $1992-96$ & 158 & 23 & 0.11 & 21 & 0.046 & 0.016 & 379 & 938 & 60 & 31 & 7.2 & 16 & 13 & 1265 \\
\hline \multicolumn{15}{|c|}{3 Slurry, Dec. } \\
\hline 1992-93 & 115 & 9.5 & 0.060 & 8.7 & 0.022 & 0.008 & 218 & 78 & 14 & 5.4 & 3.3 & 2.4 & 0.47 & 158 \\
\hline 1993-94 & 24 & 2.9 & 0.009 & 2.8 & 0.005 & 0.001 & 61 & 234 & 82 & 51 & 0.82 & 23 & 19 & 1220 \\
\hline $1994-95$ & 10 & 1.1 & 0.002 & 0.86 & 0.001 & 0.000 & 26 & 244 & 100 & 56 & 0.92 & 30 & 22 & 1680 \\
\hline 1995-96 & 8.5 & 2.1 & 0.006 & 1.9 & 0.003 & 0.000 & 17 & 139 & 2.4 & 0.54 & 0.34 & 0.90 & 0.52 & 447 \\
\hline $1992-96$ & 158 & 16 & 0.077 & 14 & 0.031 & 0.009 & 322 & 695 & 198 & 113 & 5.4 & 56 & 42 & 3505 \\
\hline \multicolumn{15}{|c|}{4 Slurry, May } \\
\hline 1992-93 & 110 & 9.1 & 0.094 & 8.2 & 0.023 & 0.005 & 233 & 118 & 8.3 & 0.64 & 5.3 & 0.66 & 0.050 & 289 \\
\hline 1993-94 & 18 & 2.6 & 0.014 & 2.4 & 0.004 & 0.000 & 48 & 316 & 8.8 & 4.8 & 1.1 & 1.3 & 0.83 & 250 \\
\hline 1994-95 & 0.9 & 0.091 & 0.000 & 0.086 & 0.001 & 0.001 & 2.4 & 327 & 7.2 & 2.4 & 1.4 & 1.8 & 1.2 & 268 \\
\hline 1995-96 & 3.1 & 2.1 & 0.004 & 1.9 & 0.003 & 0.000 & 8.5 & 140 & 2.7 & 0.52 & 0.34 & 1.1 & 0.85 & 209 \\
\hline 1992-96 & 132 & 14 & 0.11 & 13 & 0.031 & 0.006 & 292 & 901 & 27 & 8.4 & 8.1 & 4.9 & 2.9 & 1016 \\
\hline \multicolumn{15}{|c|}{5 NPK, May } \\
\hline 1992-93 & 115 & 9.4 & 0.056 & 8.5 & 0.023 & 0.007 & 243 & 109 & 7.1 & 1.4 & 2.4 & 0.86 & 0.078 & 333 \\
\hline 1993-94 & 13 & 1.8 & 0.004 & 1.7 & 0.002 & 0.001 & 33 & 207 & 6.8 & 4.0 & 0.70 & 0.88 & 0.52 & 189 \\
\hline $1994-95$ & 0.1 & 0.016 & 0.000 & 0.012 & 0.000 & 0.000 & 0.78 & 258 & 11 & 5.2 & 1.0 & 2.0 & 1.5 & 205 \\
\hline $1995-96$ & 3.5 & 2.4 & 0.004 & 2.1 & 0.004 & 0.000 & 9.3 & 145 & 2.1 & 0.31 & 0.26 & 1.1 & 0.54 & 648 \\
\hline $1992-96$ & 132 & 14 & 0.064 & 12 & 0.029 & 0.008 & 286 & 719 & 27 & 11 & 4.4 & 4.9 & 2.6 & 1375 \\
\hline
\end{tabular}


Vol. 7 (1998): 569-581.

the final snowmelt in March was entirely surface runoff. During the ley years, the proportion of surface runoff in autumn, winter-spring and summer was $31-100 \%, 100 \%$ and $49-100 \%$, respectively. Surface runoff was exceptionally high in treatment 2 in 1993-94.

In spite of frost extending to a depth of 20 $\mathrm{cm}$ at the end of December 1992, there was altogether 75-88 $\mathrm{mm}$ of drainage flow (total runoff $89-116 \mathrm{~mm}$ ) from the ploughed frozen soil in autumn 1992. In the grass ley, the frozen layer was shallower in autumn, but there was only 8$14 \mathrm{~mm}$ of drainage flow (total runoff 26-46 mm) in autumn 1993 and no drainage in autumn 1994 (total runoff 43-77 $\mathrm{mm}$ ) and 1995 (total runoff 5-7 mm). The amounts of meltwater were about $80,15,45$ and $5 \mathrm{~mm}$ during the frozen periods in autumn 1992, 1993, 1994 and 1995, respectively.

\section{$\mathrm{N}$ and $\mathrm{P}$ losses in drainage water}

In 1992-93, the loss of $\mathrm{NO}_{3}-\mathrm{N}$ in drainage water was statistically significantly higher $(\mathrm{P}<$ 0.05 ) from treatment 2 (slurry application in September with immediate ploughing) than from the other treatments. The difference $\left(5-7 \mathrm{~kg} \mathrm{ha}^{-1}\right.$, Table 5) occurred almost totally in autumn 1992, when the amount of drainage water was much higher than during the rest of the year (107-126 vs. $3-10 \mathrm{~mm}$ ). For TP and $\mathrm{PO}_{4}$-P, however, the slightly greater losses from treatment 2 in 1992-93 (Table 5) were not statistically significant. The concentration of $\mathrm{P}$ in drainage water was low throughout the experimental period: the annual mean concentration was $0.012-0.068 \mathrm{mg}^{1^{-1}}$ for TP and 0.001-0.032 $\mathrm{mg} \mathrm{l}^{-1}$ for $\mathrm{PO}_{4}-\mathrm{P}$.

With the decreasing drainage after the first experimental year, $\mathrm{N}$ and $\mathrm{P}$ losses in drainage water were reduced and the losses did not vary with the treatment. Statistical analysis of the soil mineral nitrogen data in 1994-95 showed that, although the preceding autumn and winter applications of slurry had increased statistically significantly $(\mathrm{P}<0.05)$ the values of soil mineral $\mathrm{N}$ in spring in the surface $(0-20 \mathrm{~cm})$ and near surface layers $(20-40 \mathrm{~cm})$, the values below 40 $\mathrm{cm}$ were not affected (results not shown).

\section{$N$ and $P$ losses in surface runoff}

$\mathrm{N}$ losses in surface runoff were low in the control plot and decreased towards the end of the experiment (Table 5). Slurry application and immediate ploughing in September 1992 did not affect the $\mathrm{N}$ loss in surface runoff.

From 1993 onwards, $\mathrm{N}$ losses varied with the fertilization practice. Compared with spring applications (treatments 4 and 5), TN losses in surface runoff were very much greater after surface application of slurry in autumn (treatment 2) and especially in winter (treatment 3) in 1993-94 and 1994-95. Surface application of slurry in autumn and winter increased the losses of $\mathrm{NH}_{4}-\mathrm{N}$ and organic $\mathrm{N}$, while the loss of $\mathrm{NO}_{3}-\mathrm{N}$ was little affected (Table 5). The peak concentrations of $\mathrm{NH}_{4}-\mathrm{N}$ in surface runoff following the applications were 4-12 $\mathrm{mg} \mathrm{l}^{-1}$ for the autumn and 50$200 \mathrm{mg} \mathrm{l}^{-1}$ for the winter applications (Fig. 2).

At the start of the experiment, concentrations of TP and $\mathrm{PO}_{4}$-P in surface runoff from ploughed soil were $0.06-2.2 \mathrm{mg} \mathrm{l}^{-1}$ and $0.010-0.11 \mathrm{mg} \mathrm{l}^{-1}$, respectively. During the experiment, TP losses in the control plot decreased, while $\mathrm{PO}_{4}-\mathrm{P}$ concentrations and losses increased slightly relative to the ploughed soil (Fig. 2, Table 5). TP and $\mathrm{PO}_{4}-\mathrm{P}$ concentrations and losses in surface runoff were not increased after slurry application and immediate ploughing in September 1992.

In contrast, $\mathrm{TP}$ and $\mathrm{PO}_{4}-\mathrm{P}$ losses were drastically increased after autumn and winter surface applications of slurry in 1993-94 and 1994-95 (Table 5). In surface runoff samples taken after the surface applications in autumn and winter, concentrations of $\mathrm{PO}_{4}-\mathrm{P}$ peaked with highest values of 10 $25 \mathrm{mg} \mathrm{l}^{-1}$ (Fig. 2). Although the increase was smaller than for the autumn and winter applications, TP and $\mathrm{PO}_{4}-\mathrm{P}$ losses were also increased after slurry and fertilizer applications in spring.

$\mathrm{P}$ losses from plots of winter-applied slurry and mineral fertilizer occurred mainly in winter-spring during the highest runoff, while au- 
Turtola, E. \& Kemppainen, E. $N$ and P losses after application of fertilizers to grass ley

\section{Control}

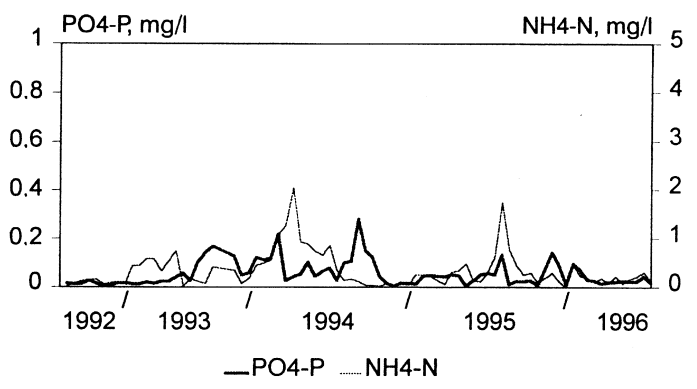

Slurry, Sept.

Slurry, Dec.
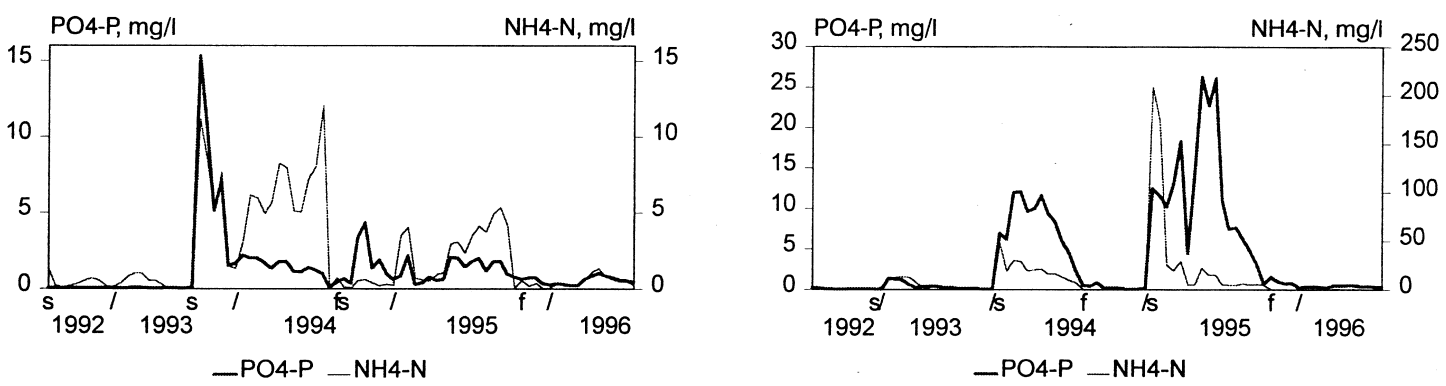

Slurry, May

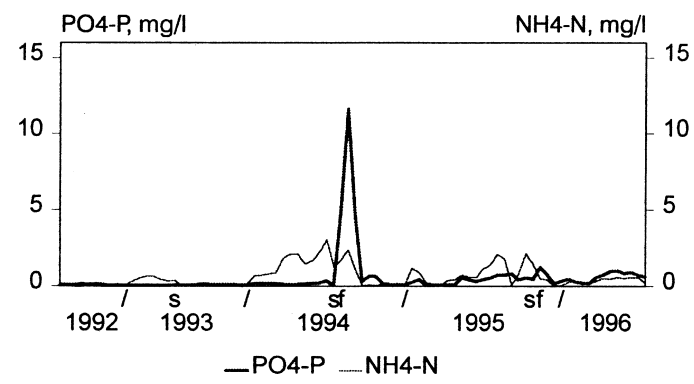

NPK, May

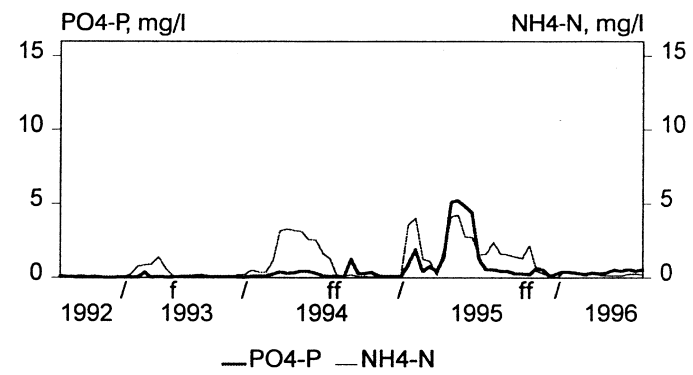

Fig. 2. Concentrations of dissolved orthophosphate phosphorus $\left(\mathrm{PO}_{4}-\mathrm{P}\right)$ and ammonium nitrogen $\left(\mathrm{NH}_{4}^{-} \mathrm{N}\right)\left(\mathrm{mg} \mathrm{l}^{-1}\right)$ in surface runoff in 1992-1996 in the different treatments. Turn of the year denoted by ' $/$ ' and application times of slurry and mineral fertilizer by ' $s$ ' and ' $f$ '. Note the different scales on the y-axes.

tumn-applied slurry induced large losses in autumn 1993 and 1994 and spring-applied slurry considerable losses in summer-autumn 1994. Besides showing peaks after surface application of $\mathrm{P}$, the $\mathrm{PO}_{4}-\mathrm{P}$ concentration gradually increased above the base level, to $0.4-0.6 \mathrm{mg} \mathrm{l}^{-1}$ at the end of the experiment (treatments $2-5$ ). In the con- trol treatment the concentration remained well below $0.2 \mathrm{mg} \mathrm{l}^{-1}$ (Fig. 2).

Loss of particulate phosphorus (PP) in surface runoff from ploughed soil and barley in 1992-93 was $0.61-0.78 \mathrm{~kg} \mathrm{ha}^{-1} \mathrm{a}^{-1}$ (91-95\% of $\mathrm{TP}$, treatments 1,2,4 and 5). The growth of ley decreased the loss of PP: loss from the control 
Vol. 7 (1998): 569-581.

Table 6. Dry matter yield $\left(\mathrm{kg} \mathrm{ha}^{-1}\right)$ in 1993-96.

\begin{tabular}{llrrrr}
\hline No & Treatment & $\begin{array}{r}1993 \\
\text { Barley }\end{array}$ & $\begin{array}{r}1994 \\
\text { Ley }\end{array}$ & $\begin{array}{r}1995 \\
\text { Ley }\end{array}$ & $\begin{array}{r}1996 \\
\text { Ley }\end{array}$ \\
\hline 1 & Control & 1610 & 1250 & 1540 & $-{ }^{1}$ \\
2 & Slurry, Sept. & 2750 & 7530 & 7980 & 1950 \\
3 & Slurry, Dec. & 2790 & 5150 & 4730 & 1370 \\
4 & Slurry, May & 3310 & 7320 & 9250 & 1040 \\
5 & NPK, May & 3840 & 8220 & 11970 & 1320 \\
\hline
\end{tabular}

${ }^{1}$ Negligible, not measured

Table 7. Nitrogen and phosphorus input in fertilizer and slurry, removal in harvested crop, surface runoff and drainage water and calculated balance (input-removal) $\left(\mathrm{kg} \mathrm{ha}^{-1}\right)$, with percentage of applied in parenthesis, during 1992-1996.

\begin{tabular}{llll}
\hline No Treatment & Input & Removal & Balance \\
\cline { 2 - 4 } & Crop & $\begin{array}{l}\text { Surface runoff }+ \\
\text { drainage water }\end{array}$ & \\
\hline
\end{tabular}

\begin{tabular}{|c|c|c|c|c|c|c|c|c|}
\hline \multicolumn{9}{|c|}{ Nitrogen } \\
\hline 1 & Control & 0 & 45 & & 30 & & -75 & \\
\hline 2 & Slurry, Sept. & 772 & 317 & (41) & 82 & (11) & 373 & \\
\hline 3 & Slurry, Dec. & 807 & 213 & (26) & 216 & (27) & 378 & \\
\hline 4 & Slurry, May & 805 & 381 & (47) & 41 & $(5.1)$ & 383 & \\
\hline 5 & NPK, May & 510 & 531 & (104) & 41 & $(8.0)$ & -62 & \\
\hline \multicolumn{9}{|c|}{ Phosphorus } \\
\hline 1 & Control & 0 & 6.4 & & 1.4 & & -7.8 & \\
\hline 2 & Slurry, Sept. & 141 & 45 & (32) & 16 & (11) & 80 & (57) \\
\hline 3 & Slurry, Dec. & 119 & 29 & (24) & 57 & (48) & 33 & (28) \\
\hline 4 & Slurry, May & 143 & 52 & (36) & 4.9 & (3.4) & 86 & (60) \\
\hline 5 & NPK, May & 107 & 61 & (57) & 4.9 & $(4.6)$ & 41 & (38) \\
\hline
\end{tabular}

plot in 1993-96 was $0.04-0.18 \mathrm{~kg} \mathrm{ha}^{-1} \mathrm{a}^{-1}$ (24$60 \%$ of TP). For the spring applications of slurry and mineral fertilizer, PP loss was $0.25-0.60$ $\mathrm{kg} \mathrm{ha}^{-1} \mathrm{a}^{-1}$ (23-51\% of TP). The greater losses following autumn and winter applications of slurry on the soil surface (0.9-1.2 and $1.9-8 \mathrm{~kg}$ $\mathrm{ha}^{-1} \mathrm{a}^{-1}$, respectively) indicated considerable losses of slurry derived PP, which was either in particulate inorganic/organic or in dissolved organic form.

\section{Calculated $\mathrm{N}$ and $\mathrm{P}$ balances}

The amount of $\mathrm{N}$ applied in slurry and mineral fertilizer was the main factor determining the dry matter yield, and the low $\mathrm{N}$ and $\mathrm{P}$ uptakes in the control treatment were mostly due to $\mathrm{N}$ deficiency. The highest yields were obtained from the mineral fertilizer treatment (Table 6). The $\mathrm{N}$ balance indicated a depletion in soil for both the control and the mineral fertilizer treatment (Table 7). Total $\mathrm{N}$ input was higher but crop uptake lower for the slurry treatments than the mineral fertilizer treatment, resulting in larger balance values. Slurry applications in autumn and spring resulted in the highest accumulation (balance) of $\mathrm{P}$ in soil, partly due to the larger amounts of $\mathrm{P}$ applied. Winter application of slurry induced large losses of $\mathrm{P}$ in runoff, which reduced the accumulation. $\mathrm{P}$ accumulation in soil in the mineral fertilizer treat- 
Turtola, E. \& Kemppainen, E. $N$ and P losses after application of fertilizers to grass ley

ment was lower compared with slurry application in spring due to the lower applied amount and the higher removal in the harvested crop.

\section{Discussion}

The proportion and amount of surface runoff were increased during the ley years of the study. An increase in the proportion of surface runoff from perennial ley compared with that from barley (soil ploughed in autumn) was also observed on a clay soil in southern Finland (Turtola and Jaakkola 1995, Turtola and Paajanen 1995) and on a loam soil in southern Norway (Uhlen 1978a). Young and Mutchler (1976) measured more surface runoff during spring snowmelt from alfalfa plots compared with ploughed corn plots and explained the difference in terms of smaller depressional storage of water and longer lasting frost on the alfalfa plots.

Besides the larger amount of water in snow, the probable reasons for the abundant surface runoff during cultivation of perennial ley in the present study were the deep and prolonged frost in combination with surface soil compaction. Both factors decreased the water conductivity in the surface layers. After ploughing, the depressional storage to retard surface runoff was larger and the frozen ploughed soil seemed to be more porous due to the recent tillage, enabling water penetration and drainage water flow especially in autumn. During the winter-spring period, however, most of the pores were probably closed by occasional meltwater freezing into the pores thus also increasing the proportion of surface runoff from the ploughed soil.

Low infiltration of water and surface application of slurry proved to be a highly risky combination for $\mathrm{N}$ and $\mathrm{P}$ losses from ley. $\mathrm{N}$ and $\mathrm{P}$ compounds were directly lost from the surfaceapplied slurry in autumn and winter, as shown by the extremely high $\mathrm{PO}_{4}-\mathrm{P}$ and $\mathrm{NH}_{4}-\mathrm{N}$ concentrations and losses in surface runoff. These concentrations were very similar to those measured by Edwards \& Daniel (1993) in runoff from grass-covered plots exposed to simulated rainfall $24 \mathrm{~h}$ after surface application of swine slurry and also to those of Edwards et al. (1996) for pasture fields receiving poultry manure. Likewise, Uhlen (1978b) and Braun and Leuenberger (1991) measured similar $\mathrm{PO}_{4}-\mathrm{P}$ concentrations in surface runoff from grassland after off-season manure application without incorporation. Young and Mutchler (1976) reported similar $\mathrm{NH}_{4}-\mathrm{N}$ concentrations in surface runoff from alfalfa plots receiving dairy manure and slurry in autumn or winter. $\mathrm{N}$ and $\mathrm{P}$ losses in the present study attributable to surface application of slurry in autumn and winter were larger than any previously reported losses from cultivated soil in Finland and strongly argue for further restrictions on surface application of slurry on grasslands during autumn.

Although less risky than the applications in autumn and winter, also the spring and summer applications on the soil surface induced much larger $\mathrm{PO}_{4}-\mathrm{P}$ losses, with high concentration peaks, than the control treatment or preceding barley. The increase was due to a combination of increased surface runoff from ley, direct loss from surface applied $\mathrm{P}$ and accumulation of $\mathrm{P}$ in the soil surface. The accumulation of $P$ in the soil surface during the experiment has been separately studied by Turtola and Yli-Halla (1999), who showed that the P not taken up by plants or removed by runoff was accumulated in a shallow layer less than $5 \mathrm{~cm}$ thick. Subsequently, the base level of the $\mathrm{PO}_{4}-\mathrm{P}$ concentration in surface runoff was increased, from $0.01-0.11 \mathrm{mg} \mathrm{l}^{-1}$ in 1992 up to $0.4-0.6 \mathrm{mg} \mathrm{l}^{-1}$ in spring 1996. Turtola and Jaakkola (1995) found that repeated surface application of mineral fertilizer $\mathrm{P}$ on grass ley on a heavy clay soil raised the base level of $\mathrm{PO}_{4}-\mathrm{P}$ concentration in surface runoff during three years from less than 0.1 to $0.5 \mathrm{mg} \mathrm{l}^{-1}$, with concentration peaks $\left(2-5 \mathrm{mg} \mathrm{l}^{-1}\right)$ immediately after the application. The peaks and the increase in the base level of $\mathrm{PO}_{4}$-P concentration demonstrate the environmental risks associated with the surface applications of fertilizers common in perennial ley cultivation. 
Vol. 7 (1998): 569-581.

Compared with surface application, incorporation of the autumn applied slurry by immediate ploughing effectively impeded $\mathrm{P}$ losses. The increase in $\mathrm{N}$ leaching in drainage water $(5 \mathrm{~kg}$ $\mathrm{ha}^{-1}$ ) relative to the control treatment was small probably because of a slow mineralization of $\mathrm{NH}_{4}-\mathrm{N}$ in the prevailing conditions (low soil temperature in autumn, long-lasting frost). In Minnesota, USA, Young and Mutchler (1976) observed that $\mathrm{N}$ loss in surface runoff was not significantly increased from manured, fall ploughed plots. In Norway, Uhlen (1978b) found that mixing the manure into the soil efficiently reduced P losses. Data of Niinioja (1993) for a clay soil in eastern Finland suggest no increase in $\mathrm{N}$ and $\mathrm{P}$ leaching due to autumn incorporation of slurry in comparison with mineral fertilizer treatment. However, considerable increases in nutrient leaching after autumn application of slurry have been measured in warmer climate with high drainage flow during winter or large quantities of applied nutrients (Oskarsen et al. 1996, Carey et al. 1997, Paul and Zebarth 1997).

The lower losses of $\mathrm{N}$ and $\mathrm{P}$ in surface runoff from winter-applied slurry in the first year were probably partly due to more intensive adsorption of $\mathrm{NH}_{4}^{+}$and $\mathrm{H}_{2} \mathrm{PO}_{4}^{-}$on the ploughed soil surface compared with the ley surface in the later years.

The average $\mathrm{PO}_{4}-\mathrm{P}$ concentration in surface runoff from the control plot was slightly higher during the three ley years $(0.081,0.046$ and 0.086 $\mathrm{mg} \mathrm{l}^{-1}$, respectively) compared with the preceding barley cultivation $\left(0.025 \mathrm{mg} \mathrm{l}^{-1}\right)$. This can probably be attributed to $\mathrm{PO}_{4}-\mathrm{P}$ release from the grassy vegetation. In the study of Uhlen (1988), for example, $\mathrm{PO}_{4}-\mathrm{P}$ concentration in surface runoff from unfertilized grassland was in the range $0.1-0.2 \mathrm{mg}^{-1}$ during spring, with even higher concentrations at the outset of snowmelt. In both the present study and that of Uhlen (1988) the resulting $\mathrm{PO}_{4}$-P losses were 4-5 times as large as losses from ploughed, unfertilized soil. Also McDowell et al. (1989) have reported that $\mathrm{PO}_{4}^{-}$
$P$ concentrations in almost half of the runoff samples from unfertilized, continuous cotton exceeded $0.2 \mathrm{mg} \mathrm{l}^{-1}$, and attributed these, in part, to the release of soluble $\mathrm{P}$ from crop residues.

The low level of $\mathrm{P}$ found in the drainage water is not surprising as $\mathrm{P}$ accumulation was observed only in the $0-5 \mathrm{~cm}$ layer (Turtola and YliHalla 1999). The low P status and large amounts of oxalate-extractable $\mathrm{Fe}$ and $\mathrm{Al}$ below the plough layer promoted the adsorption of dissolved P from infiltrating water. After applying slurry in an amount approximately 10 times the grass requirement, Unwin (1980) found no increase of $\mathrm{P}$ in soil leachates, although $\mathrm{P}$ was accumulated in the 0-30 cm soil layer. Similarly, Dam Kofoed and Søndergaard Klausen (1986), Furrer and Stauffer (1986), Kemppainen (1995) and Cameron et al. (1996) found no increase in $\mathrm{P}$ leaching through lysimeters after application of slurry or manure on mineral soils.

A large part of $\mathrm{N}$ from the surface-applied slurry was probably lost through ammonia volatilization, which was not measured. Carey et al. (1997) found that in two years following the surface application of pig slurry on a pasture soil (N $200 \mathrm{~kg} \mathrm{ha}^{-1} \mathrm{a}^{-1}$, comparable to the amount applied in our study), the sum of denitrification and volatilization was $56 \%$ of the applied N. Atmospheric losses might thus explain much of the large balance (input-removal) values for $\mathrm{N}$ in the slurry treatments.

Acknowledgements. The contributions of the following persons and institutes are acknowledged with gratitude: $\mathrm{Mr}$ Aulis Järvi for planning the layout of the experimental field, West Finland Regional Environment Centre for establishing the field, Mr Unto Nikunen for field work, Ms Raili Tirkkonen and Ms Helena Merkkiniemi for laboratory analyses, Mr Eero Miettinen for the statistical analysis, $\mathrm{Mr}$ Pekka Heikkinen for calculating most of the results, Dr Markku Yli-Halla for description of the soil profile, Ms Pirkko Laitinen for providing data on soil hydrological characteristics, Ms Kathleen Ahonen for linguistic revision of the manuscript, and the Ministry of Agriculture and Forestry for funding. We also wish to thank the two anonymous referees for their useful comments. 


\section{AGRICULTURAL AND FOOD SCIENCE IN FINLAND}

Turtola, E. \& Kemppainen, E. $N$ and P losses after application of fertilizers to grass ley

\section{References}

Braun, M. \& Leuenberger, J. 1991. Abschwemmung von gelösten Phosphor auf Ackerland und Grasland während den Wintermonaten. Landwirtschaft Schweiz 4: 555-560.

Cameron, K.C., Rate, A.W., Noonan, M.J., Moore, S., Smith, N.P. \& Kerr, L.E. 1996. Lysimeter study of the fate of nutrients following subsurface injection and surface application of dairy pond sludge to pasture. Agriculture, Ecosystems and Environment 58: 187197.

Carey, P.L., Rate, A.W. \& Cameron, K.C. 1997. Fate of nitrogen in pig slurry applied to a New Zealand pasture soil. Australian Journal of Soil Research 35: 941959.

Dam Kofoed, A. \& Søndergaard Klausen, P. 1986. Leaching of nutrients from sewage sludge and animal manure. In: Dam Kofoed, A. et al. (eds.). Efficient land use of sludge and manure. London: Elsevier. p. 116127.

Eder, G. \& Harrod, T.R. 1996. Influence of grassland on soil erosion, aggregate stability and water quality. In: Parente, G. et al. (eds.). Grassland and land use systems. Proceedings of the 16th General Meeting of the European Grassland Federation, Grado (Gorizia), Italy, 15-19 September 1996. Gorizia: Organizing Committee of the 16th General Meeting of the European Grassland Federation. ERSA, Ente Regionale per la Promozione e lo Sviluppo dell'Agricolture Via Montesanto. p. 683-693.

Edwards, D.R. \& Daniel, T.C. 1993. Runoff quality impacts of swine manure applied to fescue plots. Transactions of the American Society of Agricultural Engineers 36: 81-86.

-, Daniel, T.C., Murdoch, J.F. \& Moore, P.A.Jr. 1996. Quality of runoff from four Northwest Arkansas pasture fields treated with organic and inorganic fertilizer. Transactions of the American Society of Agricultural Engineers 39: 1689-1696.

Esala, M. 1991. Split application of nitrogen: effects on the protein in spring wheat and fate of ${ }^{15} \mathrm{~N}$-labelled nitrogen in the soil-plant system. Annales Agriculturae Fenniae 30: 219-309. (Diss.)

FAO, 1988. FAO/Unesco Soil Map of the World, Revised Legend, with corrections. World Resources Report 60, FAO, Rome. Reprinted as Technical Paper 20, ISRIC, Wageningen, The Netherlands. $140 \mathrm{p}$.

Furrer, O.J. \& Stauffer, W. 1986. Influence of sewage sludge and slurry application on nutrient leaching losses. In: Dam Kofoed, A. et al. (eds.). Efficient land use of sludge and manure. London: Elsevier. p. 108115.

Kemppainen, E. 1989. Nutrient content and fertilizer value of livestock manure with special reference to cow manure. Annales Agriculturae Fenniae 28: 163-284.

- 1995. Leaching and uptake of nitrogen and phosphorus from cow slurry and fox manure in a lysimeter trial. Agricultural Science in Finland 4: 363-375.

Kähäri, J. \& Nissinen, H. 1978. The mineral element contents of timothy (Phleum pratense) in Finland. I. Acta
Agriculturae Scandinavica, Supplement 20: 26-39.

MMM 1998. Maatalouden ympäristöohjelma 1995-1999. Seurantatyöryhmän loppuraportti. Työryhmämuistio MMM 5/1998. Maa- ja metsätalousministeriö. Helsinki. ISSN 0781-6723. 102 p., 70 p.

McDowell, L.L., Willis, G.H. \& Murphree, C.E. 1989. Nitrogen and phosphorus yields in runoff from silty soils in the Mississippi Delta, U.S.A. Agriculture, Ecosystems \& Environment 25: 119-137.

Misselbrook, T.H., Pain, B.F., Stone, A.C. \& Scholefield, D. 1995. Nutrient run-off following application of livestock wastes to grassland. Environmental Pollution 88: $51-56$.

Niinioja, R. 1993. Lietelannan levitys ja ravinteiden huuhtoutuminen. (Leaching of nutrients from land application of slurry). Vesi- ja ympäristöhallinnon julkaisuja $A$. Helsinki. 87 p.

Niskanen, R., 1989. Extractable aluminium, iron and manganese in mineral soils. II. Extractability by oxalate and pyrophosphate. Journal of Agricultural Science in Finland 61: 79-87.

Oskarsen, H., Haraldsen, T.K., Aastveit, A.H. \& Myhr, K. 1996. The Kvithamar field lysimeter II. Pipe drainage, surface runoff and nutrient leaching. Norwegian Journal of Agricultural Sciences 10: 211-228.

Parkes, M.E., Campbell, J. \& Vinten, A.J.A. 1997. Practice to avoid contamination of drainflow and runoff from slurry spreading in spring. Soil Use and Management 13: 36-42.

Paul, J.W. \& Zebarth, B.J. 1997. Denitrification and nitrate leaching during the fall and winter following dairy cattle slurry application. Canadian Journal of Soil Science 77: 231-240.

Soil Survey Staff 1992. Keys to Soil Taxonomy, 5th ed. SMSS technical monograph No. 19, Blacksbury, Virginia. $541 \mathrm{p}$.

Turtola, E. \& Jaakkola, A. 1995. Loss of phosphorus by surface runoff and leaching from a heavy clay soil under barley and grass ley in Finland. Acta Agriculturae Scandinavica Sect. B, Soil and Plant Science 45: 159-165.

- \& Paajanen, A. 1995. Influence of improved subsurface drainage on phosphorus losses and nitrogen leaching from a heavy clay soil. Agricultural Water Management 28: 295-310.

- \& Yli-Halla, M. 1999. Fate of phosphorus applied in slurry and mineral fertilizer: accumulation in soil and release into surface runoff water. Nutrient cycling in Agroecosystems. In press.

Uhlen, G. 1978a. Nutrient leaching and surface runoff in field lysimeters on a cultivated soil. I. Runoff measurements, water composition and nutrient balances. Meldinger fra Norges landbrukshøgskole 57,27. $26 \mathrm{p}$.

- $1978 b$. Nutrient leaching and surface runoff in field lysimeters on a cultivated soil. II. Effects of farm yard manure spread on a frozen ground and mixed in the soil on water pollution. Meldinger fra Norges landbrukshøgskole 57,28. 23 p. 
Vol. 7 (1998): 569-581.

- 1988. Surface runoff losses of phosphorus and other nutrient elements from fertilized grassland. Norwegian Journal of Agricultural Sciences 3: 47-55.

Unwin, R.J. 1980. Phosphorus accumulation and mobility from large applications of slurry. In: Hucker, T.W.G. \& Catroux, G. (eds.). Phosphorus in sewage sludge and animal waste slurries, Dordrecht: Reidel. p. 333344.

- 1986 . Leaching of nitrate after application of organic manures. Lysimeter studies. In: Dam Kofoed, A. et al. (eds.). Efficient land use of sludge and manure. London: Elsevier. p. 158-167.

Vuorinen, J. \& Mäkitie, O., 1955. The method of soil testing in use in Finland. Agrogeological Publications 63: $1-14$.

Young, R.A. \& Mutchler, C.K. 1976. Pollution potential of manure spread on frozen ground. Journal of Environmental Quality 5: 174-179.

\title{
SELOSTUS
}

\section{Typen ja fosforin kulkeutuminen pinta- ja salaojavalunnassa lietelannalla ja NPK-lannoitteella lannoitetulta nurmelta}

\author{
Eila Turtola ja Erkki Kemppainen \\ Maatalouden tutkimuskeskus
}

Typen ja fosforin kulkeutumista heinänurmelta tulleissa valumavesissä tutkittiin Toholammilla hietamaalla kokeessa, jossa oli viisi lannoituskäsittelyä: ei lannoitusta (1), naudan lietelannan levitys syksyllä (2), talvella (3) tai keväällä (4) ja NPK-lannoitus keväällä (5). Koejäsenille 1-5 levitettiin kokeen aikana (1992-96) typpeä yhteensä 0, 772, 807, 805 ja $510 \mathrm{~kg} \mathrm{ha}^{-1}$ ja fosforia $0,141,119,143 \mathrm{ja} 107 \mathrm{~kg} \mathrm{ha}^{-1}$. Nurmen perustamisvuonna 1992-93, kun maa oli kynnetty syksyllä 1992, salaojavalunnan osuus kokonaisvalunnasta (salaojavalunta + pintavalunta) oli 48$60 \%$. Syksyllä multaamalla tehty lietteen levitys (käsittely 2) aiheutti hieman suuremman typen kulkeutumisen ( $\left.21 \mathrm{~kg} \mathrm{ha}^{-1}\right)$ kuin käsittelyt 1, 4 ja $5(17 \mathrm{~kg}$ $\left.\mathrm{ha}^{-1}\right)$, mutta fosforin kulkeutuminen $\left(0.7-0.9 \mathrm{~kg} \mathrm{ha}^{-1}\right)$ ei lisääntynyt. Nurmen viljelyn aikana (1993-96) sa- laojavalunta väheni ja pintavalunnan osuus kokonaisvalunnasta oli 83-100\%. Nurmelle pintaan levitetty ja käyttämättä jäänyt lannoitefosfori lisäsi ortofosfaattikuormitusta pintavalunnassa, minkä lisäksi syksyllä ja talvella levitetystä lietelannasta aiheutui myös erittäin korkeita suoria ortofosfaattifosfori- ja ammoniumtyppipäästöjä. Nurmelle syksyllä ja talvella pintaan levitetyn lietteen typpihuuhtoutuma oli $11 \%$ ja $33 \%$ levitetystä typpimäärästä ja fosforihuuhtoutuma $17 \%$ ja $59 \%$ levitetystä fosforimäärästä. Typpeä huuhtoutui käsittelyistä 1-5 kolmen nurmivuoden aikana yhteensä 13, 62, 191, 23 ja $24 \mathrm{~kg} \mathrm{ha}^{-1}$, josta ammoniumtypen osuus oli $21,49,56,33$ ja $39 \%$. Fosforia kulkeutui $0.73,16,54,4.2$ ja $4.0 \mathrm{~kg} \mathrm{ha}^{-1}$, josta ortofosfaattifosforin osuus oli 52, 85, 77, 68 ja $64 \%$. 
AGRICULTURAL AND FOOD SCIENCE IN FINLAND 